University of Nebraska - Lincoln

DigitalCommons@University of Nebraska - Lincoln

Faculty Publications - Textiles, Merchandising Textiles, Merchandising and Fashion Design, and Fashion Design

Department of

$1-2009$

\title{
Rural Consumers' Online Shopping for Food and Fiber Products as a Form of Outshopping
}

\author{
Sharon J. Lennon \\ University of Delaware, Newark, lennon@udel.edu \\ Young $\mathrm{Ha}$ \\ University of Nebraska - Lincoln, yha3@unl.edu \\ Kim K. P. Johnson \\ University of Minnesota, St.Paul, kjohnson@umn.edu \\ Cynthia R. Jasper \\ University of Wisconsin, Madison, crjasper@wisc.edu \\ Mary Lynn Damhorst \\ lowa State University, mldmhrst@iastate.edu \\ See next page for additional authors
}

Follow this and additional works at: https://digitalcommons.unl.edu/textiles_facpub

Part of the Art and Design Commons

Lennon, Sharon J.; Ha, Young; Johnson, Kim K. P.; Jasper, Cynthia R.; Damhorst, Mary Lynn; and Lyons, Nancy, "Rural Consumers' Online Shopping for Food and Fiber Products as a Form of Outshopping" (2009). Faculty Publications - Textiles, Merchandising and Fashion Design. 20.

https://digitalcommons.unl.edu/textiles_facpub/20

This Article is brought to you for free and open access by the Textiles, Merchandising and Fashion Design, Department of at DigitalCommons@University of Nebraska - Lincoln. It has been accepted for inclusion in Faculty Publications - Textiles, Merchandising and Fashion Design by an authorized administrator of DigitalCommons@University of Nebraska - Lincoln. 


\section{Authors}

Sharon J. Lennon, Young Ha, Kim K. P. Johnson, Cynthia R. Jasper, Mary Lynn Damhorst, and Nancy Lyons 


\title{
Rural Consumers' Online Shopping for Food and Fiber Products as a Form of Outshopping
}

\author{
Sharron J. Lennon, University of Delaware, Newark \\ Young Ha, University of Nebraska-Lincoln \\ Kim K. P. Johnson, University of Minnesota, St. Paul \\ Cynthia R. Jasper, University of Wisconsin, Madison \\ Mary Lynn Damhorst, Iowa State University, Ames \\ Nancy Lyons, South Dakota State University, Brookings
}

Corresponding author - Sharron J. Lennon, PhD, Irma Ayers Professor, 213 Alison Hall West, Department of Fashion and Apparel Studies, University of Delaware, Newark, DE 19716-7301; email lennon@udel.edu

\begin{abstract}
The purpose of the research was to longitudinally investigate rural consumers' online shopping for food and fiber products as a function of satisfaction with local retailing and outshopping. Innovation diffusion theory was used to guide the research. Eight hundred seventy-nine rural consumers from 11 states completed surveys twice (in 2000 and 2003). Data were analyzed using structural equation modeling and analyses of variance. Dissatisfaction with local retailing in 2000 was a powerful driver of outshopping, beliefs about online shopping, and online shopping (both in 2000 and in 2003). Outshopping was positively related to online shopping at both points in time, suggesting that variables found to affect outshopping in the literature may affect online shopping in a similar way.
\end{abstract}

Keywords: rural consumers, online shopping, clothing shopping, outshopping, satisfaction

The Internet is a significant technology (Dickson, 2000; Malecki, 2002) that is affecting communication and commerce worldwide, including rural areas. An extensive literature links communication technology and change in rural communities (Caplow, 1982; Hoover, 1990; Lynd \& Lynd, 1929, 1937; Ogburn \& Gilfillan, 1933; Vidich \& Bensman, 1968). For example, the development of the microchip and its application to home computers, the expansion of the in- home shopping industry, and Internet commercialization have eliminated, or provide the potential to eliminate, rural-urban distinctions based on time or space constraints (Dickson, 2000; Dordick \& Wang, 1993; Lubar, 1993; MacKay, 1997). Although Internet use has significant implications for rural consumers, research that focuses on Internet use in rural areas is limited (Grimes, 2000). As such, rural consumer use of the Internet is important to study. 
Shifting demographic trends reveal increasing numbers of rural elderly with disabilities (DePoy \& Gilson, 2003), a decline in some rural populations, and a parallel decline in rural retail outlets (Vias, 2004), all of which can affect satisfaction with local shopping options. Physical disabilities may make shopping difficult; fewer rural retail outlets mean less access to consumer goods in rural communities. Two general types of products are purchased outside rural communities-namely, food and fiber products (e.g., clothing, towels, sheets, curtains). Outshopping, buying goods outside one's local retail trade area, is common in rural areas (Hawes \& Lumpkin, 1984) and has a long research history (Darden \& Perreault, 1976; Finch \& Jones, 1994; Home, 2002; Jarratt \& Polonsky, 1993; Marjanen, 2000; Papadopoulos, 1980; Piron, 2002; Polonsky \& Jarratt, 1992; Samli, Riecken, \& Yavas, 1983; Thompson, 1971). Outshopping is a function of shoppers' satisfaction with local facilities and selection, with greater dissatisfaction resulting in more outshopping (Miller \& Kean, 1997; Papadopoulos, 1980; Samli et al., 1983). Online shopping can be construed as outshopping because goods are acquired out of the local trading area. In fact, Piron (2001) suggested that outshopping research results may be applicable to research on online shopping.

Online shopping may become increasingly viable for rural consumers, who can use it to purchase items not immediately available. Food and fiber products were our focus because they are often purchased nonlocally by rural consumers. Accordingly, the purpose of the research was to longitudinally investigate variables (outshopping behavior, satisfaction with local retailing) that affect rural consumers' online shopping for food and fiber products. Research objectives were as follows: (a) to test diffusion theory in the context of online shopping; (b) to describe and compare levels of satisfaction with local retail- ing, outshopping frequency, and online shopping frequency for the target products; and (c) to describe changes in online shopping and changes in belief scores as they relate to the adoption of online shopping for the target products.

\section{Theoretical Framework}

One theory that predicts adoption of new technologies such as online shopping is innovation diffusion theory (IDT; Rogers, 1995). IDT focuses on what factors affect decisions to adopt technology and how diffusion of the innovation occurs. In IDT, beliefs are proposed as precursors to behavior (adoption of an innovation). This view is consistent with both the theory of reasoned action (Ajzen \& Fishbein, 1980; Fishbein \& Ajzen, 1975) and the theory of planned behavior (Ajzen, 1985), which hold that beliefs about a behavior are antecedent to performing the behavior. IDT also posits that contextual variables affect beliefs.

IDT (Rogers, 1995) includes a model of the innovation decision-making process, which is a mental process that people experience that begins with learning about an innovation through adoption and that ends with rejection or continued acceptance of the innovation. Innovations include any objects, ideas, and practices that are perceived as being new, such as use of the Internet to shop. Diffusion involves the process by which innovations are communicated among the members of a social system and how individuals adopt or reject those innovations. Rogers (1995) identified five stages in the decision-making process.

Stage 1 is the knowledge stage, in which people develop an understanding of an innovation and its functions (e.g., learning about online shopping). Prior conditions - such as previous practice, norms of the social sys- 
tem, and characteristics of individuals - influence knowledge in Stage 1 and shape beliefs regarding innovations in Stage 2. Two important types of prior conditions include consumers' satisfaction with local retailing and the extent to which they shop out of the local retail community.

In Stage 2, persuasion, consumers form attitudes toward the innovation based on their knowledge of the innovation, their underlying beliefs, and their continued exposure to and experience with the innovation. During this stage, beliefs about online shopping (e.g., "Prices are reasonable"), perceived risks associated with online shopping, and relative benefits (e.g., "Internet shopping is useful") are important. Beliefs about online shopping are important because knowing about such an innovation does not guarantee that it will be adopted; to adopt an innovation, consumers must believe it to be useful or relevant (Rogers, 1995).

In Stage 3, decision, consumers decide to adopt or reject online shopping based on attitudes and underlying beliefs. In Stage 4, implementation, consumers take action on the decision made in Stage 3, perhaps becoming frequent online shoppers. Finally, in Stage 5, confirmation, consumers reconsider online shopping as a function of their satisfaction or dissatisfaction and opt to continue or discontinue use.

In studying innovation diffusion, longitudinal research offers several advantages over cross-sectional research. First, longitudinal research is needed to study change. Second, compared to cross-sectional studies, longitudinal studies do not rely as much on respondents' recall to reconstruct the timing of adoption and rejection. Finally, in longitudinal research, an assessment can be made of those who adopted but later rejected an innovation, rather than simply combine them with those who never adopted. This is an important potential contribution of our research to IDT because the theory often focuses on adopters alone as a function of its pro-innovation bias.

\section{Online Shopping}

Details on the demographic characteristics of the online shopper are evolving. In 2004, the Kiplinger Monitor wrote that the average U.S. online shopper had a household income of $\$ 64,063$, was 47 years old, and spent $\$ 717$ yearly online ("Online Shopping," 2004). Credit card security (Lester, Forman, \& Loyd, 2005; "Online Shopping," 2004) and disclosure of personal information (Maney \& Dugas, 1997; Novak, Hoffman, \& Peralta, 1998; "Online Shopping," 2004) continue to be barriers for online purchasing.

The frequency of online shopping and the amount of money spent online continue to grow. One source predicted that online sales would reach $\$ 117$ billion by 2008 , reflecting $10 \%$ of total sales and over 63 million households ("Statistics for Online Purchases," 2005). Yet, U.S. online sales exceeded $\$ 143$ billion in 2005 and were expected to reach $\$ 211$ billion in 2006 (Burns, 2006b). U.S. holiday shoppers spent $\$ 12$ billion online during November 2006 alone. This figure represents a \$2 billion increase from the same period the previous year (Burns, 2006a). Apparel as a category continued to stay in high demand, given that shoppers spent $\$ 1.4$ billion more on apparel than they did on consumer electronics, and home furnishings was reported to be one of the fastest-growing categories online (e-tailing group, 2005). Online spending for home furnishings equaled $\$ 19.8$ billion during the first quarter of 2005, an increase of nearly $24 \%$ over the same period the previous year (Home Furnishings Now, 2005). As such, the following sections present a summary of research focusing on shopping online for clothing, food, and home-furnishing products. 


\section{Online Clothing Shopping}

Research concerning online clothing shopping includes the factors that motivate and inhibit such shopping (Goldsmith \& Goldsmith, 2002); the relationships among search behavior, attitudes toward the Internet, beliefs about the Internet, and buying intention (Y. Kim, Kim, \& Kumar, 2003; Watchravesringkan \& Shim, 2003; Yoh, Damhorst, Sapp, \& Lazniak, 2003); and the quality and satisfaction of the clothing Web sites (S. Kim \& Stoel, 2004). Factors that inhibit online clothing shopping include the inability to try on clothing, concerns about credit card security (E. Y. Kim \& Kim, 2004; Kwon \& Lee, 2003; Xu \& Paulins, 2005), and difficulty assessing quality ( $\mathrm{Lu} \&$ Rucker, 2006). Factors that motivate online clothing shopping include the convenience, fun, and quickness of buying online; prior experience with the Internet (Lu \& Rucker, 2006; Xu \& Paulins, 2005; Yoh et al., 2003), availability of transportation (Xu \& Paulins, 2005); and confidence in ability to purchase clothing online (Goldsmith \& Goldsmith, 2002). Not surprisingly, consumers who hold positive attitudes toward online shopping and the Internet (Y. Kim et al., 2003; Yoh et al., 2003), who perceive Internet shopping as being socially acceptable (Yoh et al., 2003), who have previous Internet shopping experience, who are familiar with the brands carried (Park \& Stoel, 2005), and who search for information online (M. A. J. Kim \& Park, 2005; Watchravesringkan \& Shim, 2003) are likely to make clothing purchases online.

\section{Online Food Shopping}

Hansen (2005) studied U.S. online consumers to determine what discriminated online grocery shoppers from those who did not purchase groceries online. He found that perceived compatibility of online grocery shopping discriminated between non-online shoppers, online shoppers who had not purchased groceries online, and online grocery purchasers. Perceived risk, however, did not distinguish the three groups. Morganosky and Cude (2000) surveyed 243 U.S. users of an online grocery service; respondents were primarily young, highly educated women. Convenience was cited by $73 \%$ as the primary reason for using the service, whereas $14.8 \%$ cited physical constraints; of those, $28 \%$ were older than 55. In a follow-up study, convenience was still found to be the most important reason $(76.5 \%)$, and physical constraints was still the second most important reason $(14.7 \%)$ for buying groceries online (Morganosky \& Cude, 2002). In a small online survey of university staff in the United Kingdom, Rafiq and Fulford (2005) found that respondents placed more importance on convenience than on variety or price as reasons that they purchased groceries online.

Tanskanen, Yrjölä, and Holmström (2002) maintain that effectiveness of the e-grocery business depends on customer density, which suggests that rural areas could not support a pure e-grocery business. The researchers also maintain that the relative cost of acquiring a new e-grocery customer is high in relation to profit margin. This finding underscores the importance of enhancing in-store customer loyalty as a way to convert in-store customers to online customers. In fact, in their study, Rafiq and Fulford (2005) found that for the two most successful grocers studied, $92 \%$ and $76 \%$ of in-store shoppers also shopped the online store. This finding is consistent with a PricewaterhouseCoopers report (Clark, 2000) that found that of Internet users surveyed, $43 \%$ would be more likely to purchase groceries online if they could do so from their regular store. 


\section{Online Home-Furnishing Products Shopping}

Research that addresses online shopping for home-furnishing products is scarce and its focus is scattered. Nitse, Parker, Krumwiede, and Ottaway (2004) reported that nearly 30\% of their study's respondents would purchase home decorations online, such as wall hangings. However, respondents were concerned with product color, and $59 \%$ said that they would return home decorations if the color of the product was different from the on-screen representation.

In the same year, Worthy et al. (2004) conducted technology use experiments with rural consumers from six states. The authors were interested in the extent to which guided use of Web sites that sold clothing, home-furnishing products, and food might lead to attitude change among non-Internet users. As compared to participants who had no guided experience, those who had the guided experience had more positive attitudes toward use of the Internet to purchase clothing, homefurnishing products, and food.

Dinlersoz and Hernández-Murillo (2004) noted that although products such as those for home furnishings did not initially sell well online, sales were experiencing sharp growth. Retail Forward (2006) reported that many shoppers of home-furnishing products use the Internet to compare prices and products but want to see and touch the products before purchasing them. However, the report also indicated that the number of people buying home-furnishing products online was expected to grow. Taken together, these research findings suggest that consumers are increasingly willing to purchase home furnishing products online.

\section{Rural Consumers}

In the United States, 56 million people live in rural areas, which account for about $80 \%$ of the nation's land (Whitener \& McGranahan, 2003). According to the U.S. Census Bureau $(1995,2004 a), 21.4 \%$ of the U.S. population lived in rural areas in 2000, a decline of $24.8 \%$ over 1990 . About $30 \%$ of the rural population is 60 years or older, compared to $28 \%$ of the urban population (U.S. Census Bureau, 2004b), and households including one or more elderly person (65 years old and older) account for a greater proportion of rural households (22.2\%) than urban households (20.7\%; U.S. Census Bureau, 2004a). In addition, approximately $55 \%$ of rural consumers older than 65 report at least one disability (DePoy \& Gilson, 2003), suggesting that at least some of them find it difficult to shop in stores. Given these statistics, age and health-related disabilities are overrepresented among rural consumers, and such disabilities might encourage consumers to try forms of nonstore shopping, including online shopping.

\section{Outshopping}

As travel outside rural communities became easy, rural consumers began to shop elsewhere (Henderson, 1990, 1994), and downtown rural retailing declined. The dwindling number of retailers in some rural communities (Stone, 1989, 1995) led to fewer local options for acquiring goods and services (Vias, 2004). Alba et al. (1997) suggested that nonstore retail formats (e.g., online shopping) may be attractive in areas that lack a well-developed retail industry (e.g., some rural areas). Thus, some rural consumers may travel in order to shop in regional malls and discount outlets (Leistritz, Ayres, \& Stone, 1992), or they may increasingly use alternatives such as online shopping. Shrinking local retail options give rural consumers limited access to the basic goods, such as food and fiber products. In an analysis of the 2004 holiday season, research company Hitwise found U.S. 
rural consumers to be $16 \%$ more likely than other consumers to shop online (Internet Retailer, 2004). More recently, rural consumers in Wales were found to be more likely than urban consumers to shop online (Ping Wales, 2006). Several researchers have found that distance from retail stores is positively related to online purchasing (Farag, Weltevreden, van Rietbergen, Dijst, \& van Oort, 2006; Sinai \& Waldfogel, 2004). Thus, online shopping may be attractive and beneficial to rural consumers, especially, those who are aging, homebound, disabled, or far from stores. For example, as previously noted, Morganosky and Cude (2000) found that $14.8 \%$ of e-grocery shoppers cite physical constraints, such as being disabled, as the reason that they shop online for groceries. However, little is known about rural consumers' use of online shopping, if satisfaction with local retailing affects whether rural consumers shop online, or if shopping outside the rural community is related to online shopping.

Outshopping is the practice of leaving a local retail trade area to purchase a product or service. It is common in rural communities in the United States (Hawes \& Lumpkin, 1984) and elsewhere, such as Finland (Home, 2002; Marjanen, 2000) and Australia (Jarratt \& Polonsky, 1993; Polonsky \& Jarratt, 1992). In research on traditional rural outshopping, clothing is identified as a product likely to be purchased out of town (Finch \& Jones, 1994; Jarratt \& Polonsky, 1993; Marjanen, 2000). Darden and Perreault (1976) studied outshopping and type of product purchased; they found different types of outshoppers, such as those who buy appearance-related products (clothing, jewelry) and those who outshop for expensive home products. Home (2002) studied rural grocery outshopping in Finland and found that about two thirds of the sample outshopped for groceries.

Researchers have operationalized outshopping inconsistently. Herrmann and
Beik (1968), Thompson (1971), Reynolds and Darden (1972), and Anderson and Kaminsky (1985) used the number of shopping trips out of the local trading area; however, each study specified a different number of trips as constituting outshopping. For Herrmann and Beik, it was one trip per year; for Thompson and Anderson and Kaminsky, it was one trip in 6 months; and for Reynolds and Darden, it was 12 or more trips per year. Others have operationalized outshopping as the proportion of purchases in dollars made out of the local trading area (Samli \& Uhr, 1974).

Miller, Kim, and Schofield-Tomschin (1998) operationalized inshopping as the percentage of shopping for clothing and home furnishings items conducted with local merchants; the authors conceptualized an inshopping-outshopping continuum. Miller (2001) also measured frequency of inshopping and used an inshopping-outshopping continuum. In the current research, we assessed outshopping frequency and conceptualized it as a continuum.

Research on traditional outshopping examines which consumers purchase goods outside their home communities and why they do it. In more than 40 years of research, researchers have consistently found that outshopping is inversely related to satisfaction with local shopping conditions, such as parking (Piron, 2001), product quality (Piron, 2001; 2002; Thompson, 1971), merchandise selection, and price (Herrmann \& Beik, 1968; Papadopoulos, 1980; Piron 2001, 2002; Thompson, 1971). Alternatively but supporting the same idea, Miller and Kean (1997) found that intent to shop within one's rural community (as compared to intent to outshop) is positively and most strongly predicted by satisfaction with local retailing. Based on this rationale, Hypothesis 1 was developed.

Hypothesis 1: Satisfaction with local retailing is negatively related to outshopping frequency. 
Prior conditions, such as satisfaction with local retailing, affect beliefs about the innovation at the persuasion stage of the decisionmaking process (Rogers, 1995). This notion is consistent with research on innovations. Olshavsky and Spreng (1996) identified cognitive processes that influence the evaluation of innovations, including forming judgments about the innovation, calculating satisfaction with the currently used (or old) product, comparing the old product to the new (innovation), and forming a belief about whether the new product is better than the old. After assessing satisfaction with the old product, some consumers examined their beliefs about the new product. The research was exploratory, but it suggests that satisfaction with the old product leads to less positive beliefs about the new product. Extending this rationale, we expect satisfaction with current modes of shopping (analogous to an old product) to be negatively related to beliefs about online shopping. Wixom and Todd (2005) have reported empirical support for a general relationship between satisfaction and beliefs. Hypothesis 2 was formulated on the basis of this rationale.

Hypothesis 2: Satisfaction with local retailing is negatively related to beliefs about the Internet and online shopping.

Outshopping can be construed as a precursor to online shopping adoption. In IDT, outshopping can be classified as previous practice, which is hypothesized to predict adoption of the innovation, online shopping. No research was found that studied outshopping in relation to beliefs about the Internet and online shopping. However, outshopping and general beliefs are related. Beliefs that prices and selection are better in foreign retail environments are related to international outshopping (Piron, 2002; Tansuhaj, Ong, \& McCullough, 1989). Piron (2002), Papadopoulos (1980), and Thompson (1971) found that outshopping was related to beliefs about poor-quality merchandise, poor selection of merchandise, and high prices. Because outshopping is related to dissatisfaction with the local retail market, we expected outshopping to be positively related to beliefs about the Internet and online shopping, which led to Hypothesis 3.

Hypothesis 3: Outshopping frequency is positively related to beliefs about the Internet and online shopping.

Both the theory of reasoned action (Ajzen \& Fishbein, 1980; Fishbein \& Ajzen, 1975) and the theory of planned behavior (Ajzen, 1985) posit that beliefs about a behavior affect performance of the behavior. Thus, in the context of online shopping, it is reasonable to expect that beliefs about online shopping and the Internet will influence decisions to shop online. Indeed, Lee and Littrell (2005) found that beliefs about a commercial Web site affected purchase intent from that Web site. This idea is consistent with that by Rogers (1995), who noted that beliefs affect the initial adoption decision and decisions about continued use of an innovation. Olshavsky and Spreng (1996) also suggested that beliefs are related to adoption. Finally, Porter and Donthu (2006) found that beliefs about the Internet affect attitudes toward and use of the Internet, whereas Monsuwe, Dellaert, and de Ruyter (2004) argue that beliefs about ease of use, usefulness, and enjoyment affect online shopping intent. These considerations provided the rationale for Hypothesis 4 .

Hypothesis 4: Beliefs about the Internet and online shopping are related to online shopping purchase frequency in 2000.

Rogers (1995) contended that previous practice, such as past experience, affects adoption of innovations. There is considerable support for such a relationship: Internet 


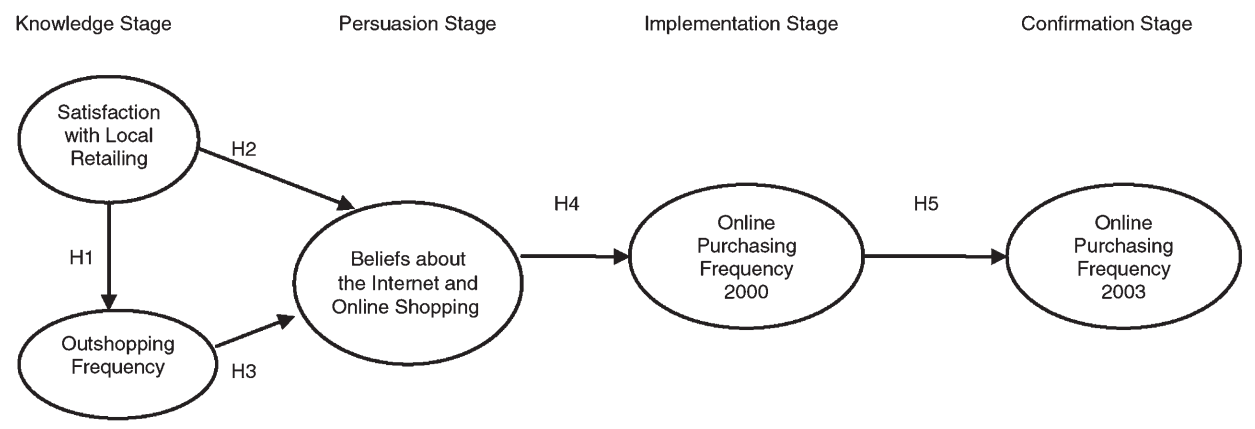

Figure 1. Proposed Model and Hypotheses

use experience is related to online purchasing (Bellman, Lohse, \& Johnson, 1999; Bhatnagar, Misra, \& Rao, 2000; Citrin, Sprott, Silverman, \& Stem, 2000; Goldsmith \& Goldsmith, 2002; Lohse, Bellman, \& Johnson, 2000; Miyazaki \& Fernandez, 2001; Siu \& Cheng, 2001; Slyke, Comunale, \& Belanger, 2002). Online shopping intent is related to previous online search experience (Shim, Eastlick, Lotz, \& Warrington, 2001). Finally, intent to purchase clothing online is predicted by previous experience with another nonstore medium catalogs (Goldsmith \& Flynn, 2005; Yoh et al., 2003). Based on this rationale, Hypothesis 5 was formulated (see Figure 1 for proposed model comprising Hypotheses 1-5).

Hypothesis 5: Online shopping in 2000 is positively related to online shopping purchase frequency in 2003.

Given the nature of innovation diffusion as a process (Rogers, 1995) and the research presented in support of the first five hypotheses, we expected indirect effects among the variables measured. For instance, we have argued that rural consumers have reason to be dissatisfied with local shopping choices. Research shows that dissatisfaction with local shopping choices drives outshopping. Rural consumers have fewer stores from which to shop in their communities (Vias, 2004), and we know that people are more likely to shop on- line when they have few nearby stores from which to shop (Farag et al., 2006). Sinai and Waldfogel (2004) found that online shopping likelihood is positively related to distance from retail stores. As such, we expected that among rural consumers, satisfaction with local shopping might be negatively related to online shopping. Therefore, we hypothesized the following indirect effects:

Hypothesis 6: Satisfaction with local retailing is indirectly and negatively related to beliefs about the Internet and online shopping.

Hypothesis 7: Satisfaction with local retailing is indirectly and negatively related to online purchase frequency in 2000 and 2003.

Hypothesis 8: Outshopping frequency is indirectly and positively related to online purchase frequency in 2000 and 2003.

Hypothesis 9: Beliefs about the Internet and online shopping is indirectly and positively related to online purchase frequency in 2003.

\section{Method}

\section{Pilot Study}

A preliminary form of the research instrument was pilot-tested on a random mail sample of consumers from rural communities in five states (Colorado, Minnesota, Ohio, North Dakota, South Dakota) during 
the summer of 1999 (Johnson et al., 2000). No problems were found with the questionnaire. The typical respondent was 58 years old with a college education who had lived in a community of roughly 5,600 people for nearly 28 years and who drove 23 miles per week for regular shopping. Among 162 respondents ( 84 men, 78 women), $56 \%$ did not use the Internet, and $77 \%$ indicated that they had spent nothing online during the last 6 months. However, more than $20 \%$ of respondents had purchased something online. This result indicates that among these rural consumers, a higher percentage were online shoppers than what would be expected in the general population, and it suggests that rural consumers may likely be online purchasers.

\section{Sampling for Main Study}

Areas and populations are classified as urban if located in urbanized areas and urban clusters (U.S. Census Bureau, 2005); areas are classified as rural if located outside urbanized areas and urban clusters. However, the definitions of urbanized areas and urban clusters are complex and not simply related to population size. For example, an area with a population of 2,501 may be classified as urban cluster if densely settled and adjacent to a urbanized area. Adding to the confusion regarding what is rural, the Farm Security and Rural Investment Act (2002) defines rural in three ways, depending on rural development programs. Business programs define rural as any area other than a city or town with a population of 50,000 or more residents (U.S. Department of Agriculture, 2002b); water and waste disposal programs define rural as an area with no more than 10,000 inhabitants (U.S. Department of Agriculture, 2002c); and community facility programs define rural as an area with a population of no more than
20,000 residents (U.S. Department of Agriculture, 2002a).

Researchers have also defined rural differently. Miller and colleagues (Miller, 2001; Miller \& Kean, 1997; Miller \& Kim, 1999) defined a rural area as one with a population of 10,000 or fewer, a location in a nonstandard metropolitan county or a nonstandard metropolitan statistical area, and an economy based on agriculture; however, they acknowledge that there are many definitions for $r u-$ ral community (Miller \& Kim, 1999). Polonsky and Jarratt (1992) defined a rural area as one with a population of 20,366; Wayland, Simpson, and Kemmerer (2003) used a community of 20,000 to define their rural area. Jarratt and Polonsky (1993), Sullivan and Savitt (1997), and Sullivan, Savitt, Zheng, and Cui (2002) did not specify how they defined a rural area. Home (2002) defined a rural territory as a sparsely populated area. Finally, we define rural as constituting areas in nonstandard metropolitan statistical area counties with populations of 12,500 or fewer. This definition is consistent with Code 7 of the 2003 Rural-Urban Continuum Code, where 1 is the most urban and 9 is the most rural (Economic Research Service, 2004).

A mailing list of consumers from nonstandard metropolitan statistical areas in 11 states (Colorado, Illinois, Iowa, Kentucky, Minnesota, Missouri, Nebraska, North Dakota, Ohio, South Dakota, Wisconsin) was purchased from a national sampling firm, with the intent to sample from communities with populations of 10,000 residents or fewer. However, at the time, the 2000 census figures were not yet available, and U.S. Census Bureau estimates were needed to identify appropriate zip codes. To compensate for population loss during the 1990s in some towns, we increased the upper population limit to 12,500. Targeted zip codes were provided to the sampling firm based on U.S. Census Bureau population estimates and postal re- 
cords. Extrapolating from census data (U.S. Census Bureau, 2000), we estimated that of the approximately 51 million consumers in the 11 -state region, about $26 \%$ lived in rural areas. Questionnaires were sent to heads of households $(n=8,085)$, and an equal number of households $(n=735)$ was randomly selected in each state. The 11 states differed in terms of percentages of rural and urban residents (U.S. Census Bureau, 2000), ranging from 51\% rural in Mississippi to $12 \%$ rural in Illinois. Thus, the sample was not representative of the 11 states, because the rural residents of some states were oversampled.

\section{Procedure}

Via the Salant and Dillman mail survey method (1994), a questionnaire booklet, cover letter, and self-addressed stamped envelope were mailed in May 2000. Reminder postcards were mailed 8 days later. A second questionnaire was sent to nonrespondents 3 weeks after the first mailing. Instructions indicated that (a) the adult in the household who did the most shopping should complete the questionnaire, (b) unanswered questionnaires should be returned, and (c) a results summary could be requested. No incentive was offered. In 2003, the same procedure was used, and questionnaire booklets, cover letters, and self-addressed stamped envelopes were sent to all who had responded to the 2000 survey.

\section{Instrument}

The pilot instrument was expanded, and 30 five-point Likert-type items (5 = strongly agree, 1 = strongly disagree) assessed beliefs about the Internet and online shopping. We developed some of the items, and some came from previous research (Johnson et al., 2000; Yoh \& Damhorst, 1999). Online purchasing frequencies for clothing, food, and home-furnishing products (i.e., linens, draperies, towels) were each measured using a 5-point scale $(1=$ never, 5 = at least once a week $)$. For each of the three products, outshopping frequencies and online information search were assessed using the same 5-point scale. Using another 5-point scale, respondents indicated their satisfaction ( 1 = not satisfied, 5 = satisfied $)$ with local retail shopping for clothing, food, and home furnishings in their communities. The number of people in the household, the length of time in the current community, the population of the community, age, and distance traveled weekly to shop were provided in an open-ended format. Annual household income, education, sex, disabled status, homebound status, access to the Internet ("Do you have access to the Internet?"), and use of the Internet ("Do you use the Internet?") were asked via a closed-ended format. These items were completed on both surveys.

\section{Results}

\section{Preliminary Analyses}

To estimate nonresponse bias, a comparison was made of demographic characteristics of early responders (approximately, the first 25\% to return) and late responders (approximately, the last $25 \%$ to return), given that late responders are similar to nonresponders (Armstrong \& Overton, 1977). Using two multivariate analyses of variance (one for 2000, one for 2003) with time of response (early, late) as the independent variable and with demographic characteristics as the dependent variables, no significant differences were found, $F(10,358)$, $=.596, p>.80$ (for 2000); $F(10,355)=.477, p>.90$ (for 2003). Thus, across both samples, early and late responders did not differ on distance traveled weekly to shop, number in household, 
Table 1. Demographic profile of respondents who completed both 2000 and 2003 surveys

\begin{tabular}{|c|c|c|c|}
\hline \multirow[b]{2}{*}{ Value } & \multirow[b]{2}{*}{$n$} & \multicolumn{2}{|c|}{$\begin{array}{l}\text { U.S. Rural } \\
\text { Population }\end{array}$} \\
\hline & & $\%$ & $(\%)^{\mathrm{a}}$ \\
\hline \multicolumn{4}{|l|}{ Sex } \\
\hline Male & 308 & 36.4 & 49.8 \\
\hline Female & 532 & 62.8 & 50.2 \\
\hline \multicolumn{4}{|l|}{ Age $(M=58)^{b}$} \\
\hline $21-24$ & 4 & .5 & 35.8 \\
\hline $25-44$ & 153 & 18.4 & 29.8 \\
\hline $45-64$ & 370 & 44.5 & 20.5 \\
\hline 65 and older & 304 & 36.6 & 13.9 \\
\hline \multicolumn{4}{|l|}{ Education } \\
\hline Less than high school education & 41 & 4.9 & 28.8 \\
\hline High school or equivalent & 252 & 29.8 & 35.7 \\
\hline Some college or equivalent & 309 & 36.5 & 22 \\
\hline College degree, some graduate & & & \\
\hline work, or graduate degree & 244 & 28.8 & 13.5 \\
\hline \multicolumn{4}{|l|}{ Household income } \\
\hline Under $\$ 25,000$ & 219 & 28.5 & 45.3 \\
\hline$\$ 25,000$ to $\$ 49,999$ & 282 & 36.7 & 34.9 \\
\hline$\$ 50,000$ to $\$ 74,999$ & 151 & 19.7 & 13.1 \\
\hline$\$ 75,000$ and above & 116 & 15.1 & 6.7 \\
\hline \multicolumn{4}{|l|}{ Years in community $(M=32.7)$} \\
\hline Under 15 & 203 & 24.2 & \\
\hline $15-29$ & 197 & 23.5 & \\
\hline $30-44$ & 196 & 23.3 & \\
\hline $45-59$ & 145 & 17.3 & \\
\hline 60 and above & 98 & 11.7 & \\
\hline \multicolumn{4}{|l|}{$\begin{array}{l}\text { Miles traveled for weekly } \\
\text { shopping }(M=15.4 \text { miles })\end{array}$} \\
\hline Under 15 & 496 & 60.1 & \\
\hline $15-29$ & 184 & 22.3 & \\
\hline $30-44$ & 91 & 11.1 & \\
\hline 45 and above & 54 & 6.5 & \\
\hline \multicolumn{4}{|l|}{ Community size $(M=3,525)$} \\
\hline Under 2,000 & 363 & 43.1 & \\
\hline $2,000-3,999$ & 175 & 20.7 & \\
\hline $4,000-5,999$ & 109 & 12.9 & \\
\hline $6,000-7,999$ & 84 & 10.0 & \\
\hline 8,000 and above & 112 & 13.3 & \\
\hline
\end{tabular}

a. Extrapolated from 2000 census figures (U.S. Census Bureau, 2000).

b. Age reported in 2003 data.

homebound status, report of physical disability, length of time in current community, sex, age, income, population of community, or education level.

Sample characteristics. In 2000, there were 8,085 questionnaires mailed; 2,198 respondents returned usable questionnaires $(n=$
764 men, $n=1,408$ women, $n=26$ with no information on sex) for a response rate of $28 \%$. In the second data collection, questionnaires were mailed to the 2,198 respondents. Usable questionnaires were returned by 847 consumers $(n=308$ men, $n=532$ women, $n=7$ with no information on sex), for a response rate of $38.4 \%$. This research focused on the 847 respondents who completed both questionnaires. More than $60 \%$ of respondents were women, and $37 \%$ of respondents were older than 65. Most respondents $(65 \%)$ had at least some college education. The most common income category was $\$ 25,000-\$ 49,999$. Respondents lived in communities of 3,525 people on average (range: 22 to 11,163), had resided there for an average of 32.7 years, and traveled an average of 15.4 miles per week to shop. This sample was older and better educated than the average U.S. rural consumer (see Table 1). Respondents' access and use of the Internet was fairly high, with $54.5 \%$ indicating that they had access to the Internet and with $49.5 \%$ indicating that they used the Internet. Although not exactly comparable, these figures compare fairly well with results from a survey by Pew Internet and American Life (Fox, 2004), which found that $58 \%$ of U.S. respondents between the ages of 50 and 64 use the Internet and that $22 \%$ of those older than 65 do. In 2003, 53 respondents self-identified as disabled, and 19 said that they were homebound (see Table 2). Of all who self-identified as being disabled, about $20 \%$ used the Internet in 2003 to search for information about food; the respective figures for clothing and home-furnishing products were 13\% and $11 \%$. Food was the product most often purchased online by disabled and homebound consumers in 2003.

Exploratory factor analysis. Exploratory factor analysis of the 30 belief items yielded three factors with eigenvalues greater than 1 
Table 2. Homebound and disabled respondents who searched for or purchased products online in 2000 and 2003

\begin{tabular}{lrrrr}
\hline & $\begin{array}{r}\text { Homebound: } 2000 \\
n=9(\%)\end{array}$ & $\begin{array}{r}\text { Homebound: } 2003 \\
n=19(\%)\end{array}$ & $\begin{array}{r}\text { Disabled: } 2000 \\
n=51(\%)\end{array}$ & $\begin{array}{r}\text { Disabled: } 2003 \\
n=53(\%)\end{array}$ \\
\hline $\begin{array}{l}\text { Information search } \\
\text { Food }\end{array}$ & $1(11.1)$ & $5(26.3)$ & $5(9.8)$ & $11(20.8)$ \\
Clothing & $2(22.2)$ & $5(26.3)$ & $4(7.8)$ & $7(13.2)$ \\
Home furnishings & $2(22.2)$ & $4(21.1)$ & $2(3.9)$ & $6(11.3)$ \\
& & & & \\
Product purchase & $0(0.0)$ & $4(21.1)$ & $0(0.0)$ & $6(11.3)$ \\
Food & $1(11.1)$ & $2(10.5)$ & $1(2.0)$ & $5(9.4)$ \\
Clothing & $0(0.0)$ & $1(5.3)$ & $3(5.9)$ & $3(5.7)$ \\
Home furnishings & & & & \\
\hline
\end{tabular}

that accounted for $55 \%$ of the variance. Items were dropped if factor loadings were less than .40 (Field, 2005; Loewenthal, 2001; Stevens, 1992) and if they cross-loaded at .40 or more. Based on factor loadings, Cronbach's alphas, and percentage of variance explained by each factor, the three belief factors were defined and labeled as such:

AOS: Advantages of Online Shopping COS: Compatibility of Online Shopping

BI: General Beliefs About the Internet

Reliabilities of the three factors were adequate-Cronbach's alphas were greater than $.94, .92$, and .84, respectively (see Table 3). Items within factors were summed to generate three indicators for the beliefs about the Internet and Internet shopping latent variable.

\section{Structural Equation Modeling Analysis}

The first research objective was to test IDT by examining relationships among variables identified by the theory. IDT focuses on changes in adoption, and in the context of this research, that means a focus on changes in adoption of online shopping. To assess change in adoption over time and variables related to the change, data collected in 2000 were used to predict online purchase frequency in 2000 and 2003. Structural equation modeling using LISREL 8.71 (Jöreskog \& Sörbom, 2004) was used for the analysis (see Table 4 for the input covariance matrix). The proposed model consisted of five latent variables - one exogenous latent variable $(\xi)$, satisfaction with rural retailing, and four endogenous latent variables $(\eta)$ - namely, outshopping frequency, beliefs about the Internet and Internet shopping, online purchase frequency in 2000, online purchase frequency in 2003-each of which had three manifest variables (indicators) that related to food, clothing, and home-furnishing products. Beliefs about the Internet and Internet shopping had as indicators the three belief factors.

Model fit. Figure 2 illustrates model fit indices and parameter estimates for the proposed model. Because the chi-square statistic is sensitive to a large sample size, the significant value for the model was not surprising, $x^{2}=315.57, d f=85, p<.001$. All other fit indices suggest that the proposed model fits the data reasonably well: adjusted goodness of fit index $=.93$, non-normed fit index $=.95$, 
Table 3. Factor loadings and reliability scores of the three belief factors

Factor and Items Factor Loadings

Factor 1: Advantages of Online Shopping ${ }^{\mathrm{a}}$

Shopping on the Internet is faster than shopping in stores.

Products purchased using the Internet are delivered quickly.

Shopping via the Internet is easy.

Internet shopping sites carry the brands I like. $\quad .732$

$\begin{array}{ll}\text { Internet shopping is convenient. } & .799\end{array}$

Prices of merchandise sold on the Internet are reasonable.

$\begin{array}{ll}\text { Internet shopping sites give good customer service. } & .866\end{array}$

Internet shopping sites offer good values.

Factor 1: Cronbach's $a=.947$

Factor means: $2000=2.888$. Factor means: $2003=3.050$.

Factor 2: Compatibility of Online Shopping $b$

I plan on buying things using the Internet.

Internet shopping fits with my lifestyle.

Internet shopping is useful.

Factor 2: Cronbach's $a=.926$.

Factor means: $2000=2.324$. Factor means: $2003=2.574$.

Factor 3: General Beliefs About the Internet ${ }^{\mathrm{C}}$

I like the Internet. $\quad .777$

I find it challenging to keep up-to-date with Internet applications.

$\begin{array}{ll}\text { The Internet is a great convenience. } & .631\end{array}$

It is easy for me to access the Internet. $\quad .600$

Factor 3: Cronbach's $a=.845$.

Factor means: $2000=3.341$. Factor means: $2003=3.379$.

comparative fit index $=.96$, normed fit index $=.95$, goodness of fit index $=.95$, root mean square error of approximation $=.057(90 \%$ confidence interval $=.051, .064)$.

Measurement model. Table 5 presents the measurement parameters estimated in the model and the average variance extracted of all latent constructs. All standardized path coefficients of the measurement model were significant $(\lambda=.46-.89, p<.001)$, indicating the validity of the items for each latent construct. Although some path coefficients had low values $(<.50)$, the average variance extracted of all latent constructs exceeded the critical value of .50, identified by Bagozzi and Yi (1991), Fornell and Larcker (1981), and
Segars (1997), to indicate that the measures are representative of the latent construct.

Structural model: Hypotheses testing. All path coefficients were significant in the hypothesized directions (see Figure 2). Hypothesis 1 predicted that satisfaction with local retailing would be negatively associated with outshopping frequency. Because the direct effect of satisfaction with local retailing on outshopping frequency was negative and significant $\left(\gamma_{11}=-.37, t=-8.05, p<.001\right)$, Hypothesis 1 was supported. Hypothesis 2 proposed that satisfaction with local retailing would be negatively related to beliefs about the Internet and online shopping, and this hypothesis was supported: Satisfaction with local retail- 


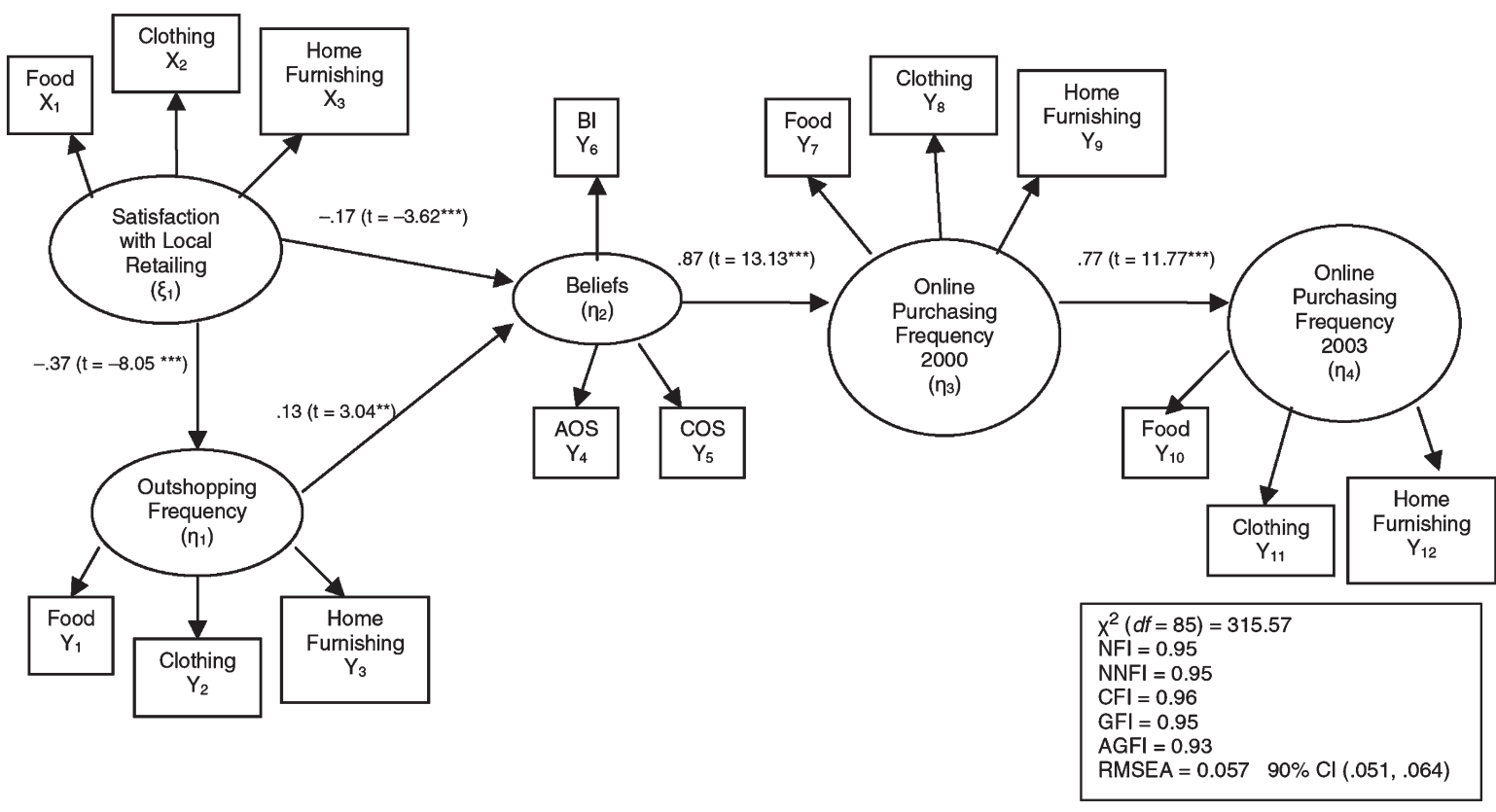

Figure 2. Model fit indices and path coefficients for structural model tested in the study All paths are significant. AOS = Advantages of Online Shopping; COS = Compatibility of Online Shopping; BI $=$ General Beliefs About the Internet.

${ }^{* *} p<.01,{ }^{* * *} p<.001$.

ing has a significant direct impact on beliefs about the Internet and online shopping $\left(\gamma_{21}=\right.$ $-.17, t=-3.62, p<.001)$, and the relationship is negative, as expected.

Hypothesis 3 predicted that outshopping frequency would be positively related to beliefs about the Internet and online shopping; the direct effect of outshopping frequency on beliefs is significant and positive $\left(\beta_{21}=.13, t=\right.$ 3.04, $p<0.01$ ), thus supporting Hypothesis 3 . Hypothesis 4 proposed that beliefs about the Internet and online shopping would be positively associated with online purchase frequency of clothing, food, and home-furnishing products in 2000. Results show a positive direct effect for beliefs about the Internet and online shopping on online purchase frequency in $2000\left(\beta_{32}=.87, t=13.13, p<.001\right)$. Thus, Hypothesis 4 was supported.
Hypothesis 5 predicted a longitudinal effect, namely, that online purchase frequency of clothing, food, and home-furnishing products in 2000 would be positively related to online purchase frequency in 2003. As expected, online purchase frequency in 2000 had a significant direct effect on online purchase frequency in $2003\left(\beta_{43}=.77, t=11.77, p<.001\right)$. Because the nature of the relationship is positive, Hypothesis 5 was supported.

Indirect effects. Satisfaction with local retailing is indirectly related to beliefs through outshopping (path coeff. $=-.05, t=-.88, p<.01$ ), thus supporting Hypothesis 6. Satisfaction with local retailing is indirectly related to online purchase frequency in 2000 (path coeff. = $-.19, t=-4.81, p<.001)$ through outshopping and beliefs, thus supporting Hypothesis 7. In 
Table 4. Covariance matrix analyzed in the study

\begin{tabular}{|c|c|c|c|c|c|c|c|c|c|c|c|c|c|c|c|}
\hline & $Y 1$ & $Y 2$ & $Y 3$ & Y4 & Y5 & $Y 6$ & $Y 7$ & Y8 & Y9 & Y10 & Y11 & Y12 & $X 1$ & $X 2$ & X3 \\
\hline$Y 1$ & 1.5164 & & & & & & & & & & & & & & \\
\hline$Y 2$ & .5394 & 1.0491 & & & & & & & & & & & & & \\
\hline$Y 3$ & .4409 & .6508 & .9878 & & & & & & & & & & & & \\
\hline$Y 4$ & .0501 & .2104 & 1692 & 1.1374 & & & & & & & & & & & \\
\hline Y5 & .0079 & .1116 & .0922 & .6833 & 1.4756 & & & & & & & & & & \\
\hline Y6 & .0618 & .1286 & .0987 & .5089 & .6487 & .7305 & & & & & & & & & \\
\hline$Y 7$ & .0002 & .0354 & .0004 & .1161 & .1754 & .1022 & .2271 & & & & & & & & \\
\hline Y8 & .0079 & .0399 & .0491 & .1869 & .3237 & .1728 & .0907 & .3002 & & & & & & & \\
\hline Y9 & .0154 & .0294 & .0612 & .0812 & .1573 & .0751 & .0499 & .1225 & .1584 & & & & & & \\
\hline Y10 & .0003 & .0284 & .0161 & .0793 & .1240 & .0428 & .0769 & .0539 & .0363 & .2994 & & & & & \\
\hline Y11 & .0181 & .0469 & .0480 & .2707 & .3890 & .2020 & .1155 & .2236 & .0933 & .1744 & .5740 & & & & \\
\hline Y12 & .0151 & .0131 & .0361 & .1069 & .1804 & .0899 & .0573 & .0824 & .0552 & .0924 & .1893 & .2171 & & & \\
\hline X1 & -.3177 & -.2359 & -.1622 & -.1827 & -.1786 & -.1390 & -.0350 & -.0707 & -.0343 & -.0702 & -.1314 & -.0370 & 1.6056 & & \\
\hline X2 & -.3374 & -.3867 & -.2751 & -.1981 & -.1848 & -.1989 & -.0529 & -.0992 & -.0487 & -.0508 & -.1159 & -.0614 & .9417 & 2.0518 & \\
\hline X3 & -.3153 & -.2940 & -.3383 & -.1491 & -.1771 & -.1477 & -.0291 & -.1032 & -.0515 & -.0556 & -.0814 & -.0714 & 1.4249 & .9534 & 0358 \\
\hline
\end{tabular}

Outshopping frequency: $Y 1=$ food, $Y 2=$ clothing, $Y 3=$ home furnishings. $Y 4=$ Advantages of Online Shopping.

$Y_{5}=$ Compatibility of Online Shopping. $Y 6=$ General Beliefs About the Internet.

Online purchasing frequency in 2000: $Y 7=$ food, $Y 8=$ clothing, $Y 9=$ home furnishings.

Online purchasing frequency in 2003: $Y 10=$ food, $Y 11=$ clothing, $Y 12=$ home furnishings.

Satisfaction with local retailing: $X 1=$ food, $X 2=$ clothing, $X 3=$ home furnishings.

addition, satisfaction with local retailing is indirectly related to online purchase frequency in 2003 through outshopping, beliefs, and online purchase frequency in 2000 (path coeff. $=-.14, t=-4.63, p<.001)$, also as predicted by Hypothesis 7 . As indicated by the $t$ values, all those relationships are negative. Furthermore, outshopping is indirectly related to online purchase frequency in 2000 (path coeff. = $.12, t=2.99, p<.01)$, and it indirectly affects online purchase frequency in 2003 (path coeff. $=.09, t=2.94, p<.01)$. The relationships are positive, and these findings support Hypothesis 8. Finally, beliefs are indirectly related to online purchase frequency in 2003 (path coeff. $=.67, t=10.44, p<.001)$, and the relationship is positive, thus supporting Hypothesis 9.

\section{Analyses of Variance}

Analyses of variance and mean comparisons were calculated from the 2003 data to address the second research objective. The independent variable is product category, which has three levels: clothing, food, homefurnishing products. Significant main effects were found for product category on satisfaction with local retailing, $F(2,822)=390.91, p$ $<.001$, on outshopping frequency, $F(2,782)=$ $150.12, p<.001$, and on online shopping frequency, $F(2,798)=49.92, p<.001$ (see Table 6 for means, standard deviations, and mean comparisons). Respondents were significantly more satisfied with local retailing for food than for clothing or home-furnishing products. Satisfaction with local retailing for home-furnishing products is significantly higher than it is for clothing, though both are slightly below the midpoint of the scale. Respondents outshopped significantly more for food than for clothing or home-furnishing products and more for clothing than for home-furnishing products. The outshopping frequency means were close to the midpoint 
Table 5. Measurement parameters estimated in the model

\begin{tabular}{|c|c|c|c|}
\hline Items & $\begin{array}{l}\text { Standardized } \\
\text { Coefficients }\end{array}$ & $t$ & $\begin{array}{l}\text { Average } \\
\text { Variance } \\
\text { Extracted }^{\mathrm{a}}\end{array}$ \\
\hline Satisfaction with local retailing $\left(\xi_{1}\right)^{\mathrm{b}}$ & & & .70 \\
\hline Shopping for food in local community $\left(x_{1}\right)$ & .63 & 18.75 & \\
\hline Shopping for clothing in local community $\left(x_{2}\right)$ & .84 & 25.99 & \\
\hline Shopping for home furnishings in local community $\left(x_{3}\right)$ & .83 & 25.76 & \\
\hline Outshopping frequency $\left(\eta_{1}\right)^{C}$ & & & .65 \\
\hline Nonlocal food stores $\left(y_{1}\right)$ & .52 & 13.79 & \\
\hline Nonlocal clothing stores $\left(y_{2}\right)$ & .85 & 22.35 & \\
\hline Nonlocal home furnishings stores $\left(y_{3}\right)$ & .75 & 20.45 & \\
\hline Beliefs about the Internet and online shopping $\left(\eta_{2}\right)$ & & & .77 \\
\hline Advantages of Online Shopping $\left(y_{4}\right)$ & .68 & 24.38 & \\
\hline Compatibility of Online Shopping $\left(y_{5}\right)$ & .83 & 26.13 & \\
\hline General beliefs of the Internet $\left(y_{6}\right)$ & .78 & 20.68 & \\
\hline Online purchasing frequency in $2000\left(\eta_{3}\right)$ & & & .54 \\
\hline Use the Internet to purchase food $\left(y_{7}\right)$ & .46 & 12.19 & \\
\hline Use the Internet to purchase clothing $\left(y_{8}\right)$ & .85 & 20.64 & \\
\hline Use the Internet to purchase home furnishings $\left(y_{9}\right)$ & .61 & 16.33 & \\
\hline Online purchasing frequency in $2003\left(\eta_{4}\right)$ & & & .58 \\
\hline Use the Internet to purchase food $\left(y_{10}\right)$ & .48 & 12.51 & \\
\hline Use the Internet to purchase clothing $\left(y_{11}\right)$ & .89 & 17.07 & \\
\hline Use the Internet to purchase home furnishings $\left(y_{12}\right)$ & .62 & 16.05 & \\
\hline
\end{tabular}

All values significant at $p<.001$.

a. Minimum standard is .50 (Bagozzi \& Yi, 1991; Fornell \& Larcker, 1981; Segars, 1997).

b. Exogenous latent variable.

c. Endogenous latent variable.

of the scale for clothing and food but somewhat lower for home-furnishing products. Clothing was purchased online significantly more than food or home-furnishing products, although no difference was found in online purchase frequency of food and home-furnishing products. Overall, purchase frequencies for all three product categories are low (less than once or twice per year), and differences, though significant, are relatively small.

Changes in online shopping. Descriptive statistics were used to address the third research objective. Twenty-one respondents purchased clothing online in 2000 but did not in 2003 (dropouts), whereas 89 did not pur- chase clothing online in 2000 but did in 2003 (new adopters) and 94 purchased clothing in 2000 and 2003 (continuous adopters). Regarding online purchases for home-furnishing products, 21 respondents were dropouts, 64 were new adopters, and 25 were continuous adopters. With respect to online food purchases, 38 respondents were dropouts, 50 were new adopters, and 30 were continuous adopters. Compared to food and home-furnishing products, more respondents adopted online shopping to purchase clothing. Table 7 presents frequencies and percentages of respondents who purchased products online in 2000 and 2003. In general, online purchasing increased among respondents for all prod- 
Table 6. Satisfaction, outshopping, and online purchasing of food, clothing, and home- furnishing products in 2003: Means, standard deviations, and comparisons

\begin{tabular}{lllc}
\hline Item & $M(S D)$ & Comparison & $\begin{array}{r}\text { Least Significant } \\
\text { Difference }(M)\end{array}$ \\
\hline $\begin{array}{l}\text { Satisfaction with local retailing } \\
\text { Food }\end{array}$ & $3.95(1.27)$ & Food versus clothing & $1.25^{* * *}$ \\
Clothing & $2.70(1.43)$ & Food versus home & $1.10^{* * *}$ \\
Home furnishings & $2.85(1.43)$ & Clothing versus home & $-0.15^{* * *}$ \\
Outshopping frequency & & & $0.31^{* * *}$ \\
Food & $3.24(1.27)$ & Food versus clothing & $0.72^{* * *}$ \\
Clothing & $2.93(1.43)$ & Food versus home & $0.41^{* * *}$ \\
Home furnishings & $2.52(0.99)$ & Clothing versus home & $-0.20^{* * *}$ \\
Online purchase frequency & & & 0.02 \\
Food & $1.17(0.55)$ & Food versus clothing & $0.22^{* * *}$ \\
Clothing & $1.37(0.76)$ & Food versus home & Clothing versus home \\
Home furnishings & $1.15(0.46)$ & & \\
\hline
\end{tabular}

$* * * p<.001$

uct categories from 2000 to 2003. In addition, whereas 155 respondents purchased one of the three products in 2000, 221 had purchased at least one of them by 2003. Thus, online purchasing increased over the 3-year period.

Changes in belief scores. Part of the third research objective was to investigate possible changes in participants' belief scores over time. To do so, we conducted paired-sample $t$ tests using mean belief factor scores across the 2000-2003 period. We were interested in the extent to which belief scores changed for dropouts, continuous adopters, and new adopters (see Table 8). There are no significant changes among dropouts' belief scores for food or home-furnishing products; there is, however, a significant drop for clothing but only for general beliefs about the Internet. No significant changes were found in belief scores for continuous adopters with respect to food. However, beliefs about the compatibility of online shopping did increase for continuous adopters of clothing.
In addition, and contrary to what IDT would predict, general beliefs about the Internet decreased for continuous adopters of homefurnishing products. Given the low number of dropouts and continuous adopters for food and home-furnishing products, the related results should not be relied on. Consistent significant changes were found in the category of new adopters across all three target product categories. For new adopters of food and clothing, all mean belief scores increased over the 3-year period. For new adopters of home-furnishing products, beliefs about the compatibility of online shopping and the advantages of online shopping increased over the period.

\section{Discussion}

Two characteristics of this research deserve mention. First, actual behavioral frequencies were measured (outshopping and online shopping frequencies). Many researchers of 
Table 7. Online shopping in 2000 and 2003 by number and percentage of respondents

\begin{tabular}{lrr}
\hline & $\begin{array}{r}\text { Purchased } \\
(2000)\end{array}$ & $\begin{array}{r}\text { Purchased } \\
(2003)\end{array}$ \\
\cline { 2 - 3 } \cline { 3 - 3 } Product & $n(\%)$ & $n(\%)$ \\
\hline Food & $114(13.46)$ & $189(22.31)$ \\
Clothing & $47(5.55)$ & $92(10.86)$ \\
Home furnishings & $17(2.00)$ & $24(2.83)$ \\
Food and clothing & $20(2.36)$ & $46(5.43)$ \\
Clothing and home furnishings & $0(0.00)$ & $3(0.35)$ \\
Food and home furnishings & & \\
Food, clothing, and home & $19(2.24)$ & $33(3.90)$ \\
$\quad$ furnishings & $155(18.30)$ & $221(26.09)$ \\
\hline
\end{tabular}

Percentages are based on the 847 respondents who responded to both surveys (2000 and 2003).

online shopping measure consumers' intentions, just as some researchers of outshopping measure outshopping or inshopping intentions. Additionally, our study is important for providing a longitudinal perspective of rural consumers' online shopping adoption for food and fiber products, whereas most other studies of online shopping are cross-sectional. Longitudinal research is important because it allows for an assessment of change.

To address the first research objective, structural equation modeling was used to examine relationships among the variables identified by IDT as being important. Among the respondents, satisfaction with local shopping for food, clothing, and home-furnishing products was negatively related to outshopping frequency (Hypothesis 1). This result is consistent with previous research (Miller \& Kean, 1997; Papadopoulos, 1980; Samli et al., 1983). Satisfaction with shopping for food, clothing, and home-furnishing products in rural communities is also negatively related to favorable beliefs about the Internet and online shopping (Hypothesis 2). This is consistent with IDT (Rogers, 1995), which posits that prior conditions, such as satisfaction with local retailing, affect belief structures. Also, the more frequently that consumers outshop for food, clothing, and home-furnishing products, the more favorable their beliefs are about the Internet and online shopping (Hypothesis 3). These findings are also consistent with Rogers's work (1995). Previous practice (e.g., shopping out of the local community) affects the knowledge stage, which in turn affects belief structures.

Favorable beliefs about the Internet and online shopping are associated with more frequent online purchasing of food, clothing, and home-furnishing products in 2000 (Hypothesis 4). This result is consistent with the research of Rogers (1995), Ajzen and Fishbein (1980), and Ajzen (1985), who all noted that beliefs about a behavior affect performance of the behavior. Online purchase of clothing, food, and home-furnishing products in 2000 is positively related to online purchasing in 2003 (Hypothesis 5). This result is consistent with the work of Rogers and others (Goldsmith \& Goldsmith, 2002; Shim et al., 2001; Yoh et al., 2003) who found that previous experience influences innovation adoption. However, rather than collect data over a longitudinal time frame, those researchers simply asked respondents about previous purchasing at the same time that they assessed current purchasing. No published research was found that focused on direct relationships between satisfaction with local retailing and rural consumers' current or future online shopping, between traditional outshopping and rural consumers' current or future online shopping, or between beliefs about online shopping and future online shopping behavior.

However, the nature of innovation diffusion as a process, with empirical research focusing on the intermediate links in our model, suggest that such relationships might form over time; to assess these possibilities, 
Table 8. Paired sample $t$ tests: Changes in belief scores (2000-2003)

\begin{tabular}{|c|c|c|c|c|}
\hline & $M$ & $S D$ & $t$ & $d f$ \\
\hline \multicolumn{5}{|c|}{ New adopters in 2003 of food online shopping } \\
\hline BI & -.36 & 0.86 & $-2.94^{* *}$ & 48 \\
\hline cOS & -.85 & 1.16 & $-5.15^{\star * *}$ & 49 \\
\hline AOS & -.72 & 0.81 & $-6.02^{* * *}$ & 45 \\
\hline \multicolumn{5}{|c|}{ New adopters in 2003 of clothing online shopping } \\
\hline BI & -.19 & 0.75 & $-2.34^{*}$ & 83 \\
\hline COS & -.88 & 1.00 & $-8.09^{* * *}$ & 84 \\
\hline AOS & -.61 & 0.78 & $-7.03^{* * *}$ & 80 \\
\hline \multicolumn{5}{|c|}{ New adopters in 2003 of home-furnishing products online shopping } \\
\hline BI & -.14 & 0.65 & -1.70 & 62 \\
\hline COS & -.85 & 1.10 & $-6.17^{* * *}$ & 62 \\
\hline AOS & -.55 & 0.86 & $-4.97^{* * *}$ & 59 \\
\hline \multicolumn{5}{|c|}{ Dropouts in 2003 of food online shopping } \\
\hline BI & .20 & 0.67 & 1.79 & 36 \\
\hline COS & -.19 & 1.06 & -1.09 & 36 \\
\hline AOS & .11 & 0.68 & 0.96 & 37 \\
\hline \multicolumn{5}{|c|}{ Dropouts in 2003 of clothing online shopping } \\
\hline BI & .55 & 0.56 & $4.51^{* * *}$ & 20 \\
\hline COS & .43 & 0.95 & 2.04 & 19 \\
\hline AOS & .10 & 0.59 & 0.76 & 19 \\
\hline \multicolumn{5}{|c|}{ Dropouts in 2003 of home-furnishing products online shopping } \\
\hline BI & .27 & 0.66 & 1.90 & 20 \\
\hline COS & .00 & 1.41 & 0.00 & 20 \\
\hline AOS & -.20 & 0.60 & -1.50 & 20 \\
\hline \multicolumn{5}{|c|}{ Continuous adopters of food online shopping } \\
\hline BI & .17 & 0.50 & 1.84 & 28 \\
\hline $\cos$ & -.24 & 1.05 & -1.28 & 29 \\
\hline AOS & -.11 & 0.60 & -1.02 & 29 \\
\hline \multicolumn{5}{|c|}{ Continuous adopters of clothing online shopping } \\
\hline BI & .03 & 0.54 & 0.53 & 91 \\
\hline COS & -.23 & 1.07 & $-2.09^{*}$ & 93 \\
\hline AOS & -.10 & 0.73 & -1.34 & 92 \\
\hline \multicolumn{5}{|c|}{ Continuous adopters of home-furnishing products online shopping } \\
\hline BI & .17 & 0.37 & $2.23^{*}$ & 23 \\
\hline cos & .23 & 0.86 & 1.31 & 24 \\
\hline AOS & .04 & 0.53 & 0.33 & 24 \\
\hline
\end{tabular}

Belief scores from 2003 were subtracted from belief scores from 2000 so that negative mean differences denote more positive beliefs. BI = Beliefs About the Internet; COS = Compatibility of Online Shopping; AOS = Advantages of Online Shopping.

${ }^{*} p<.05 ;{ }^{* *} p<.01 ;{ }^{* * *} p<.0005$

we hypothesized several indirect effects and found them to be significant. Satisfaction is indirectly and negatively related to beliefs about the Internet and online shopping (Hypothesis 6). The more satisfied consumers are with local retailing, the less favorable their beliefs are regarding the Internet and online shopping. One possible explanation is that for rural consumers, online shopping may simply be another way to shop outside the ru- 
ral community. This result is consistent with Olshavsky and Spreng's evaluation process model (1996). Applying their model to our data suggests that if consumers conceptualize online shopping as a subcategory of outshopping, they may have extended their positive beliefs about outshopping to online shopping and the Internet. If that type of extended inference did occur, then the chain of events might be as follows: Dissatisfaction with local retailing drives outshopping; rural consumers associate online shopping with outshopping-just a different way to get goods outside the rural community; because consumers like outshopping, they think that they will like online shopping (and the Internet); thus, dissatisfaction with local retailing is indirectly related to beliefs about the Internet and online shopping.

Satisfaction is also indirectly and negatively related to online purchase frequency in 2000 and 2003 (Hypothesis 7). In both cases, the more satisfied that rural consumers were with local retailing in 2000, the less frequently they purchased online in 2000 and 2003. As these relationships demonstrate, dissatisfaction with local retailing is so powerful that it continued to indirectly affect online purchase frequency 3 years after it was measured. Previous researchers had related satisfaction to outshopping but not to online shopping. This result is important, and it suggests that rural consumers may be an important potential market for online merchants, particularly when considering that access to goods in rural communities has dwindled given that the number of rural retail outlets has declined (Vias, 2004). The fact that satisfaction predicts outshopping and online shopping may suggest that outshopping and online shopping are analogous responses in the rural environment. The same variables that drive outshopping could drive online shopping; researchers might extend research on online shopping by using variables found to affect outshopping.
In addition to these indirect effects, outshopping is indirectly related to purchasing in 2000 and 2003 (Hypothesis 8), and the relationships are positive. In each case, rural consumers who frequently shop out of their rural communities for food, clothing, and homefurnishing products tend to purchase the three target categories more frequently online. Previous researchers (Piron, 2001; Wayland et al., 2003) have conceptualized online shopping as a form of outshopping but had not established the relationship empirically. Thus, rural consumers may evolve from outshopping to online shopping as an extension of outshopping behavior. These results further support the application of outshopping research findings to online shopping.

Finally, there is a significant positive indirect effect for beliefs about the Internet and online shopping on online purchase frequency for food, clothing, and home-furnishing products in 2003 (Hypothesis 9). Rural consumers holding favorable beliefs about the Internet and online shopping in 2000 tended to be frequent online purchasers of food, clothing, and home-furnishing products in 2003. Thus, beliefs as measured in 2000 influenced the decision to adopt online shopping for food, clothing, and home-furnishing products in 2000, as well as the decision to continue adopting in 2003. These results are consistent with the work of Rogers (1995), who outlined how belief structures affect the initial decision to adopt an innovation, as well as the decision to continue to adopt an innovation.

In summary, the analysis of indirect effects demonstrates that satisfaction with local retailing is negatively related to beliefs about the Internet and online shopping and that satisfaction with local retailing, outshopping frequency, and beliefs about the Internet and online shopping are important predictors of online shopping adoption by rural consumers. These results provide sup- 
port for the longitudinal nature of innovation diffusion.

To address the second research objective, we compared rural consumers' levels of satisfaction with local retailing, outshopping frequency, and online shopping frequency for the target products. Significant differences were found for satisfaction with shopping in home communities across the three products in 2003. Rural consumers were satisfied with shopping for food in their home communities and were neutral in their satisfaction with shopping for home-furnishing products and clothing. Respondents outshopped for food slightly more often than every few months; they outshopped for clothing slightly less often than every few months; and they outshopped for home-furnishing products slightly more often than once or twice a year. These differences may reflect the frequency with which these products are typically purchased. Why would respondents who like food purchasing in their rural communities outshop more frequently for food than other products? It may be that because food is perishable, it is simply likely to be purchased more frequently (both at home and away) than the other two products. Piron (2002) also found that when compared to other items, food is most frequently purchased out of the local area.

Of the three target products, respondents were least satisfied with clothing purchases in their home communities, and clothing was the product most frequently purchased online. In 2003, clothing was purchased online by more respondents than were food and home-furnishing products combined. In a similar pattern, respondents were most satisfied with food purchases in their home communities and less likely to purchase food online. This clearly demonstrates that rural consumers shop online for goods that they cannot find (or do not like) in their local communities. Our research models the way in which rural consumers' satisfaction with local retailing and their outshopping behavior influence their beliefs and subsequent online shopping adoption. Rural consumers are more likely to shop out of town when dissatisfied with shopping for food, clothing, and home-furnishing products in their rural communities. This finding is consistent with that of many researchers who found a negative relationship between outshopping and satisfaction with local retailing (Miller \& Kean, 1997; Piron, 2001, 2002).

To address the third research objective, we sought to describe changes in online shopping and changes in belief scores as they relate to adoption of the target products. In analyzing changes in mean belief scores, few significant differences were found across the dropouts and continuous adopters. This result is not surprising, given the small number of dropouts across the three product categories and the small number of continuous adopters for food and home-furnishing products. However, results for continuous adopters of clothing suggest that they may develop more positive beliefs about the compatibility of online shopping with experience. This interpretation is consistent with research that found that online purchasing is related to a variety of previous experiences (Bellman et al., 1999; Bhatnagar et al., 2000; Citrin et al., 2000; Goldsmith \& Goldsmith, 2002; Lohse et al., 2000; Miyazaki \& Fernandez, 2001; Siu \& Cheng, 2001; Slyke et al., 2002). In addition, new adopters of all three products demonstrated significant increases in eight of nine belief scores across the period. As people moved through the decision-making process, changes in belief scores became evident among the new adopters, thereby driving the adoption process.

To summarize, across the 3 years of the research, some people stopped shopping online, whereas others who had not previously shopped online began to do so. There were 
dropouts and new adopters in each product category. However, online shopping overall increased for respondents. First, the new adopters outweighed the dropouts for each of the three product categories. Second, the number of respondents who purchased all three products online increased over the 3year period.

\section{Implications}

Implications of our research are primarily theoretical. Dissatisfaction with local retailing is positively related to beliefs about the Internet and online shopping, and it was found to be a powerful driver of online shopping. The indirect satisfaction-online shopping relationship supports Olshavsky and Spreng's model (1996) of how consumers evaluate innovations (considering online shopping an innovation). After assessing satisfaction with a currently used product (e.g., local retailing), consumers examine their beliefs about the innovation and form a belief about whether the innovation is better. Dissatisfaction with local retailing influences online shopping adoption indirectly via beliefs about online shopping and the Internet. IDT does not specify satisfaction with the currently used product as a predictor of beliefs about an innovation, but we did find such evidence, suggesting that satisfaction be explicitly added to IDT as a prior condition that affects beliefs in the persuasion stage of the decision-making process. Accordingly, it may be useful to consider satisfaction with currently used products in predicting adoption of a competing innovation. Based on relationships found between outshopping and online shopping, research on online shopping might be informed by an examination of factors related to outshopping.

Given that favorable beliefs about the Internet and online shopping are related to more frequent online purchases of food, clothing, and home-furnishing products, we offer implications related to changing beliefs to encourage online shopping. Consumers with age- and health-related disabilities have been identified as an important market for e-grocery services (Heikkila, Kallio, Saarinen, \& Virpi, 1998; Morganosky \& Cude, 2000). In 2000, no respondent who was disabled or homebound indicated purchasing food online. By 2003, food was the product purchased online most often (although still at low levels) by disabled and homebound consumers. Because these consumers are older than average rural consumers, they may find it difficult to shop in stores. Morganosky and Cude (2000) found that these consumers typically live alone, have low incomes, and phone in orders instead of order online.

Because current retailers do not consider the needs of these consumers (Heikkila et al., 1998), selling and delivering groceries to disabled and homebound consumers is a service that local retailers may want to promote. Rural retailers could partner with local churches and social service agencies in this regard. For rural consumers who are mobile, a drive-up service allowing them to order by phone or online for later pickup might be appealing especially to those who are timepressed. Because our disabled and homebound respondents engaged in product information search online more frequently than they purchased products and because information search predicts purchase intent (Shim et al., 2001), rural retailers might want to establish informational Web sites. In particular, grocery stores might highlight health-related products (e.g., health foods, vitamins, minerals, supplements) and community services available on-site (e.g., free flu shot clinic).

Dissatisfaction with local retailing is positively related to beliefs about the Internet 
and online shopping, and respondents were slightly dissatisfied with clothing and home furnishings available in their home communities. In the analyses of changing beliefs, new adopters displayed significant positive changes. In other words, changing beliefs drove adoption. As telecommunication services continue to increase in rural areas, rural consumers will continue to change their beliefs about and move to online shopping. Rural retailers have an opportunity to tap into the power of the Internet while still maintaining hands-on personal relationships with customers that face-to-face interaction and personal history with retail associates can provide. Rural retailers might begin with a simple informational Web site, which could evolve into a commercial site. Store receipts could be printed with the Web site's URL. If products sold were listed, shoppers could be offered the opportunity to order online for instore pickup. A store Web site could also list information about in-store events and feature promotional items. Online shoppers and information seekers would appreciate such features.

In-store shoppers could be offered special promotions to try the online store (e.g., 10\% discount for online orders). Access to the retailer's Web site might be offered in the store via a computer terminal or kiosk to introduce non-Internet shoppers to the online presence. These features could change non-Internet shoppers' beliefs about the compatibility and advantages of online shopping, ultimately affecting the adoption of online shopping. This would be advantageous should the retailer decide to develop a commercial Web site, which would be the way to benefit from both in-store and online opportunities.

To appeal to rural consumers, online merchants far from rural areas might investigate and implement strategies aimed at changing their beliefs about the Internet and online shopping. Many successful online merchants began as catalog merchants. Rural consumers have experience ordering products from catalogs, and they do trust such merchants. These merchants might include "how to order online" information in their catalogs and offer promotions for customers who order online for the first time. They could also include instructions on how to use their Web sites in every catalog order, and they could appeal to rural consumers by highlighting speedy delivery and the advantages of online ordering over driving to a distant mall (e.g., gasoline money saved, time saved). Finally, all online merchants could include information on their Web sites for consumers far from brick-andmortar locations (e.g., free fabric swatches available by order).

\section{Limitations and Future Research}

This research has several limitations. The sample is not random, because rural residents were oversampled in some states and undersampled in others. This factor has implications for generalizability. Compared to the U.S. rural population, our sample is older, better educated, with higher household incomes. We also measured outshopping frequency for each product category using a 5-point scale $(1=$ never, $5=$ at least once a week $)$. Others have assessed outshopping using different measures-for example, by asking how many trips per month were made to outshop, how much money was spent out of the local community, what percentage of all shopping activities were conducted out of the local community, and so on. Thus, our results may not be comparable to other research. Finally, the way that we categorized consumers as rural differs somewhat from how previous research has. All these factors could be addressed in future research.

In the present study, the size of the rural community was not considered as an in- 
fluence on participants' responses; that factor could be incorporated in future research. Future research with rural consumers might also investigate the degree that cost and brand influence consumers' decisions to outshop. In addition, researchers might gain insight by studying the extent to which rural and urban consumers differ in terms of relationships among satisfaction, outshopping, and online shopping. Future researchers will want to continue to follow the evolution of rural consumers' use of the Internet, including their purchasing behaviors. Finally, our research model was developed based on Rogers's theory (1995), and it tested whether variables affect others in a sequential manner. However, it is possible that direct effects exist between the variables for which we found indirect effects: between satisfaction and current and future online purchasing, between beliefs and future online purchasing, and between outshopping and current and future online purchasing. In the future, other researchers could test such a model against ours to determine which better fits the data.

\section{References}

Ajzen, I. (1985). From intentions to actions: A theory of planned behavior. In J. Kuhland \& J. Beckman (Eds.), Action-control: From cognitions to behavior (pp. 11-39). Heidelberg, Germany: Springer.

Ajzen, I., \& Fishbein, M. (1980). Understanding attitudes and predicting social behavior. Englewood Cliffs, NJ: Prentice Hall.

Alba, J., Lynch, J., Weitz, B., Janiszewski, C., Lutz, R., Sawyer, A., et al. (1997). Interactive home shopping: Consumer, retailer, and manufacturer incentives to participate in electronic marketplaces. Journal of Marketing, 61(3), 38-53.

Anderson, C. H., \& Kaminsky, M. (1985). The outshopper problem: A group approach for small business retailers. American Journal of Small Business, 9(4), 34-45.

Armstrong, J. S., \& Overton, T. S. (1977). Estimating nonresponse bias in mail surveys. Journal of Mar- keting Research, 14, 396-402.

Bagozzi, R. P., \& Yi, Y. (1991). Multitrait-multimethod matrices in consumer research. Journal of Consumer Research, 17, 429-439.

Bellman, S., Lohse, G. L., \& Johnson, E. J. (1999). Predictors of online buying behavior. Communications of the ACM, 42(12), 32-38.

Bhatnagar, A., Misra, S., \& Rao, H. (2000). On risk, convenience, and Internet shopping behavior. Communications of the ACM, 43(11) 98-105.

Burns, E. (2006a, December). Online consumers spending more per visit this holiday. Accessed December 10, 2006, from http://www.clickz.com/showPage.html?page $=3624121$

Burns, E. (2006b, June). Online retail revenues to reach \$200 billion. Accessed December 9, 2006, from http://www.clickz.com/showPage. html?page $=3611181$

Caplow, T. (1982). Middletown families: Fifty years of change and continuity. Minneapolis: University of Minnesota Press.

Citrin, A., Sprott, D., Silverman, S., \& Stem, D. (2000). Adoption of Internet shopping: The role of consumer innovativeness. Industrial Management $\mathcal{E}$ Data Systems, 100(7), 294-300.

Clark, K. R. (2000, May 3). Grocery shopping online vs. on land: Consumers prefer to walk the aisles PricewaterhouseCoopers' survey reports. Accessed July 11, 2005, from http://www.pwc.com/extweb/ncpressrelease.nsf/docid/E5AB218CAE54206B8525 68D40052790E

Darden, W. R., \& Perreault, W. D. (1976). Identifying inter-urban shoppers: Multiproduct purchase patterns and segmentation profiles. Journal of Marketing Research, 13, 51-60.

DePoy, E., \& Gilson, S. F. (2003). Rural disabled elders. Journal of Gerontological Social Work, 41(1/2), 175-190.

Dickson, P. R. (2000). Understanding the trade winds: The global evolution of production, consumption, and the Internet. Journal of Consumer Research, 27, 115-122.

Dinlersoz, E. M., \& Hernández-Murillo, R. (2004). The diffusion of electronic business in the United States. Federal Reserve Bank of St. Louis Review, 87, 11-34.

Dordick, H., \& Wang, G. (1993). The information society. Newbury Park, CA: Sage.

Economic Research Service. (2003). Measuring rurality: Rural-urban continuum codes. Accessed January 1, 2007, from http://www.ers.usda.gov/briefing/ rurality/RuralUrbCon/ 
e-tailing group. (2005). E-facts. Accessed May 12, 2005, from http://www.e-tailing.com/newsandviews/facts.html

Farag, S., Weltevreden, J., van Rietbergen, T., Dijst, M., \& van Oort, F. (2006). E-shopping in the Netherlands: Does geography matter? Environment and Planning B: Planning and Design, 33, 59-74.

Farm Security and Rural Investment Act. (2002). Definition of rural and rural area. Accessed December 24, 2006, from http://www.rurdev.usda.gov/rd/ farmbill/2002/sections.html

Field, A. (2005). Discovering statistics using SPSS (2nd ed.). London: Sage.

Finch, J., \& Jones, K. (1994, May). Retail outshopping and recommended strategies to combat it. Regional Business Review, p. 13.

Fishbein, M., \& Ajzen, I. (1975). Belief, attitude, intention, and behavior: An introduction to theory and research. Reading, MA: Addison-Wesley.

Fornell, C., \& Larcker, D. F. (1981). Evaluating structural equation models with unobservable variables and measurement error. Journal of Marketing Research, 18, 39-50.

Fox, S. (2004). Older Americans and the Internet. Accessed January 30, 2007, from http:/ / www.pewinternet.org/pdfs/PIP_Seniors_Online_2004.pdf

Goldsmith, R. E., \& Flynn, L. R. (2005). Bricks, clicks, and pix: Apparel buyers' use of stores, Internet, and catalogs compared. International Journal of Retail \& Distribution Management, 33, 271-283.

Goldsmith, R. E., \& Goldsmith, E. B. (2002). Buying apparel over the Internet. Journal of Product and Brand Management, 11, 89-102.

Grimes, S. (2000). Rural areas in the information society: Diminishing distance or increasing learning capacity? Journal of Rural Studies, 16, 13-21.

Hansen, T. (2005). Consumer adoption of online grocery buying: A discriminant analysis. International Journal of Retail \& Distribution Management, 33, 101-121.

Hawes, J. M., \& Lumpkin, J. R. (1984). Understanding the outshopper. Journal of Academy of Marketing Science, 12, 200-218.

Heikkila, J. Kallio, J., Saarinen, T., \& Virpi, K. (1998). Grocery shopping for the elderly and disabled: Finnish EC experiments. Electronic Markets, 8(2), 389-402.

Henderson, D. (1990). Rural retail sales and consumer expenditure functions. Journal of Agricultural Economics Research, 42(3), 27-34.

Henderson, D. (1994). Estimates of retiree spending in the retail and service sectors of community. Journal of the Community Development Society, 25(2), 259-276.

Herrman, R. O., \& Beik, L. L. (1968). Shoppers' movements outside their local retail area. Journal of Marketing, 32(10), 45-51.

Home, N. (2002). Rural consumers' patronage behaviour in Finland. International Review of Retail, Distribution, and Consumer Research, 12(2), 149-164.

Home Furnishings Now. (2005, May 20). E-commerce sales soar 24 percent over year. Accessed May 23, 2005, from http:/ / www.hfnmag.com

Hoover, D. W. (1990). Middletown revisited. Muncie, IN: Ball State University.

Internet Retailer. (2004). Rural consumers 16\% more likely than urbanites to shop online, study says. Accessed January 16, 2007, from http://www.internetretailer.com/dailyNews.asp?id=13569

Jarratt, D. G., \& Polonsky, M. J. (1993). Causal linkages between psychographic and demographic determinants of outshopping behavior. International Review of Retail, Distribution, and Consumer Research, 3(3), 303-319.

Johnson, K. K. P., Bastow-Shoop, H., Gregory, S., Henderson, D., Hyllegard, K., Lakner, H., et al. (2000, November). Rural consumers' attitudes toward and use of the Internet for shopping. Paper presented at the International Textiles and Apparel Association, Cincinnati, $\mathrm{OH}$.

Jöreskog, K. G., \& Sörbom, D. (2004). LISREL 8: Users' reference guide. Lincolnwood, IL: Scientific Software International.

Kim, E. Y., \& Kim, Y.-K. (2004). Predicting online purchase intentions for clothing products. European Journal of Marketing, 38, 883-897.

Kim, M. A. J., \& Park, J. (2005). A consumer shopping channel extension model: Attitude shift toward the online store. Journal of Fashion Marketing and Management, 9, 106-121.

Kim, S., \& Stoel, L. (2004). Apparel retailers: Website quality dimensions and satisfaction. Journal of Retailing and Consumer Services, 11, 109-117.

Kim Y., Kim, E. Y., \& Kumar S. (2003). Testing the behavioral intentions model of online shopping for clothing. Clothing and Textiles Research Journal, 21, 32-40.

Kwon, K.-N., \& Lee, J. (2003). Concerns about payment security of Internet purchasers: A perspective on current on-line shoppers. Clothing and Textiles Research Journal, 21, 174-184.

Lee, S.-E., \& Littrell, M. A. (2005). Global e-tailing: US consumers' intention to shop for cultural products on the Internet. International Journal of Retail \& Distribution Management, 33, 133-147. 
Leistritz, F. L., Ayres, J. S., \& Stone, K. (1992). Revitalizing the retail trade sector in rural communities: Lessons from three Midwestern states. Economic Development Review, 10(4), 49-54.

Lester, D. H., Forman, A. M., \& Loyd, D. (2005). Internet shopping and buying behavior of college students. Services Marketing Quarterly, 27, 123.

Loewenthal, K. M. (2001). An introduction to psychological tests and scales (2nd ed.). London: Psychology Press.

Lohse, G., Bellman, S., \& Johnson, E. (2000). Consumer buying behavior on the Internet: Findings from panel data. Journal of Interactive Marketing, 14(1), 15-29.

Lu, Y., \& Rucker, M. (2006). Apparel acquisition via single vs. multiple channels: College students' perspectives in the US and China. Journal of Retailing and Consumer Services, 13, 35-50.

Lubar, S. (1993). Infoculture. Boston: Houghton Mifflin.

Lynd, R. S., \& Lynd, H. M. (1929). Middletown. New York: Harcourt Brace.

Lynd, R. S., \& Lynd, H. M. (1937). Middletown in transition. New York: Harcourt Brace.

MacKay, H. (1997). Consumption and everyday life. Thousand Oaks, CA: Sage.

Malecki, E. J. (2002). The economic geography of the Internet's infrastructure. Economic Geography, 78, 399-424.

Maney, K., \& Dugas, C. (1997, August 13). Online shopping is hard to sell. USA Today, pp. B1-B2.

Marjanen, H. (2000). Retailing in rural Finland and the challenge of nearby cities. International Journal of Retail \& Distribution Management, 28, 194-206.

Miller, N. J. (2001). Contributions of social capital theory in predicting rural community inshopping behavior. Journal of Socio-Economics, 30, 475-493.

Miller, N. J., \& Kean, R. C. (1997). Factors contributing to inshopping behavior in rural trade areas: Implications for local retailers. Journal of Small Business Management, 35, 80-94.

Miller, N. J., \& Kim, S. (1999). The importance of older consumers to small business survival: Evidence from rural Iowa. Journal of Small Business Management, 37, 1-15.

Miller, N. J., Kim, S., \& Schofield-Tomschin, S. (1998). The effects of activity and aging on rural community living and consuming. Journal of Consumer Affairs, 32, 343-368.

Miyazaki, A., \& Fernandez, A. (2001). Consumer perceptions of privacy and security risks for online shopping. Journal of Consumer Affairs, 35, 27-44.
Monsuwe, T. P., Dellaert, B., \& de Ruyter (2004). What drives consumers to shop online? A literature review. International Journal of Service Industry Management, 15, 102-121.

Morganosky, M., \& Cude, B. (2000). Consumer response to online grocery shopping. International Journal of Retail \& Distribution Management, 28, 17-26.

Morganosky, M., \& Cude, B. (2002). Consumer demand for online food retailing: Is it really a supply side issue? International Journal of Retail $\mathcal{E}$ Distribution Management, 30, 451-458.

Nitse, P. S., Parker, K. R., Krumwiede, D., \& Ottaway, T. (2004). The impact of color in the e-commerce marketing of fashions: An exploratory study. European Journal of Marketing, 38, 898-915.

Novak, T. P., Hoffman, D. L., \& Peralta, M. (1998). Building consumer trust in online environments: The case for information privacy. Accessed January 25, 2002, from http://www.ecommerce.vanderbilt. edu/papers/pdf/CACM.privacy98.PDF

Ogburn, W. F., \& Gilfillan, S. C. (1933). The influence of invention and discovery. In Report of the President's Research Committee on social trends: Recent social trends in the United States (Vol. 1, pp. 122-166), New York: McGraw-Hill.

Olshavsky, R. W., \& Spreng, R. A. (1996). An exploratory study of the innovation evaluation process. Journal of Product Innovation Management, 13, 512-529.

Online shopping. (2004, February). Kiplinger Monitor, p. 22.

Papadopoulos, N. G. (1980). Consumer outshopping research: Review and extension. Journal of Retailing, 56(4), 41-58.

Park, J., \& Stoel, L. (2005). Effect of brand familiarity, experience and information on online apparel purchase. International Journal of Retail and Distribution Management, 33, 148-160.

Ping Wales. (2006, September). Rural shoppers drive Welsh e-commerce boom. Accessed January 16, 2007, from http://www.pingwales.co.uk/2006/09/01/ Welsh-Consumer-Council.html

Piron, F. (2001). International retail leakages: Singaporeans outshopping in Malaysia. Singapore Management Review, 23(1), 35-58.

Piron, F. (2002). International outshopping and ethnocentrism. European Journal of Marketing, 36, 189-210.

Polonsky, M. J., \& Jarratt, D. G. (1992). Rural outshopping in Australia: The Bathurst-Orange region. European Journal of Marketing, 20, 5-16. 
Porter, C. E., \& Donthu, N. (2006). Using the technology acceptance model to explain how attitudes determine Internet usage: The role of perceived access barriers and demographics. Journal of Business Research, 59, 999-1007.

Rafiq, M., \& Fulford, H. (2005). Loyalty transfer from offline to online stores in the UK grocery industry. International Journal of Retail \& Distribution Management, 33, 444-460.

Retail Forward. (2006). Shopper update: Furniture/ home furnishings. Accessed January 17, 2007, from http:// documents.retailforward.com/Popup/ Popuppage.aspx?DocumentID=16\&IssueID=873

Reynolds, F. D., \& Darden, W. R. (1972). Intermarket patronage: A psychographic study of consumer outshoppers. Journal of Marketing, 36(4), 50-54.

Rogers, E. M. (1995). Diffusion of innovations (4th ed.). New York: Free Press.

Salant, P., \& Dillman, D. A. (1994). How to conduct your own survey. New York: John Wiley.

Samli, A. C., Riecken, G., \& Yavas, U. (1983). Intermarket shopping behavior and the small community: Problems and prospects of widespread phenomenon. Journal of the Academy of Marketing Science, 11(2), 1-14.

Samli, A. C., \& Uhr, B. (1974). The outshopping spectrum: Key for analyzing intermarket leakages. Journal of Retailing, 50(2), 70-78.

Segars, A. H. (1997). Assessing the unidimentionality of measurement: A paradigm and illustration within the context of information systems research. Omega, 25, 107-121.

Shim, S., Eastlick, M., Lotz, S., \& Warrington, P. (2001). An online prepurchase intentions model: The role of intention to search. Journal of Retailing, 77, 397-416.

Sinai, T., \& Waldfogel, J. (2004). Geography and the Internet: Is the Internet a substitute or complement for cities? Journal of Urban Economies, 56, 1-24.

Siu, N., \& Cheng, M. (2001). The study of the expected adoption of online shopping-The case of Hong Kong. Journal of International Consumer Marketing, 13(3), 87-106.

Slyke, C. V., Comunale, C. L., \& Belanger, F. (2002). Gender differences in perceptions of web-based shopping. Communications of the ACM, 45(7), 82-86.

Statistics for online purchases. (2005). ePaynews.com. Accessed May 23, 2005, from http://www.epaynews.com/statistics/purchases.html

Stevens, J. (1992). Applied multivariate statistics for the social sciences. Hillsdale, NJ: Lawrence Erlbaum.

Stone, K. E. (1989, May). A study of small Iowa towns with successful retail sectors. Ames: Iowa State University, Department of Economics.

Stone, K. E. (1995, June). Rural retailers: Competing with the mass merchandisers. Paper presented at the Rural Retailing Symposium, Snowbird, UT.

Sullivan, P., \& Savitt, R. (1997). Store patronage and lifestyle factors: Implications for rural grocery retailers. International Journal of Retail $\mathcal{E}$ Distribution Management, 25, 351-364.

Sullivan, P., Savitt, R., Zheng, Y., \& Cui, Y. (2002). Rural shoppers: Who gets their apparel dollars? Journal of Fashion Marketing and Management, 6, 363-380.

Tanskanen, K., Yrjölä, H., \& Holmström, J. (2002). The way to profitable Internet grocery retailing: Six lessons learned. International Journal of Retail \& Distribution Management, 30, 169-178.

Tansuhaj, P., Ong, W. C., \& McCullough, J. (1989), International outshoppers: What are they like? Singapore Marketing Review, 4, 93-97.

Thompson, J. R. (1971). Characteristics and behavior of out-shopping consumers. Journal of Retailing, 47(1), 70-80.

U.S. Census Bureau. (1995). Table 1. Urban and rural population: 1900 to 1990. Accessed October 3, 2004, from http://www.census.gov/population/censusdata/urpop0090.txt

U.S. Census Bureau. (2000). American fact finder. Accessed January 1, 2007, from http://factfinder. census.gov/home/saff/main.html?_lang_en

U.S. Census Bureau. (2004a). GCT-H6. Occupied housing characteristics: 2000. Accessed October 5, 2004, from http:/ / factfinder.census.gov

U.S. Census Bureau. (2004b). Quarterly retail e-commerce sales: 3rd quarter 2004. Accessed December 21, 2004, from http://www.census.gov/mrts/ www/current.html

U.S. Census Bureau. (2005). Summary File 1: 2000 census of population and housing. Accessed January 1, 2007, from http://www.census.gov/prod/ cen2000/doc/sf1.pdf

U.S. Department of Agriculture. (2002a). Community Facilities Grant program. Accessed July 1, 2007, from http://www.rurdev.usda.gov/rhs/cf/ brief_cp_grant.htm

U.S. Department of Agriculture. (2002b). Rural Business Enterprise Grants program. Accessed July 1, 2007, from http://www.rurdev.usda.gov/rbs/ busp/rbeg.htm

U.S. Department of Agriculture. (2002c). Water and waste programs. Accessed July 1, 2007, from http:// www.usda.gov/rus/water/programs.htm 
Vias, A. C. (2004). Bigger stores, more stores, or no stores: Paths of retail restructuring in rural America. Journal of Rural Studies, 20, 303-318.

Vidich, A. J., \& Bensman, J. (1968). Small town in mass society (Rev. ed.). Princeton, NJ: Princeton University Press.

Watchravesringkan, K., \& Shim, S. (2003). Information search and shopping intentions through the Internet for apparel products. Clothing and Textiles Research Journal, 21, 1-6.

Wayland, J. P., Simpson, L. D., \& Kemmerer, B. E. (2003). Rural retailing: Understanding the multichannel outshopper. In U. S. Tate (Ed.), Proceedings of the annual meeting of the Association of Collegiate Marketing Educators (pp. 38-47). Houston, TX: Association of Collegiate Marketing Educators.

Whitener, L. A., \& McGranahan, D. A. (2003). Rural America: Opportunities and challenges. Amber Waves, 1(1), 15-21.

Wixom, B. H., \& Todd, P. A. (2005). A theoretical integration of user satisfaction and technology acceptance. Information Systems Research, 16, 85-102.

Worthy, S. L., Hyllegard, K., Damhorst, M. L., Trautman, J., Bastow-Shoop, H., Gregory, S., et al. (2004). Rural consumers' attitudes toward the Internet for information search and product purchase. Family and Consumer Science Research Journal, 33, 517-535.

Xu, Y., \& Paulins, V. A. (2005). College students' attitudes toward shopping online for apparel products: Exploring a rural versus urban campus. Journal of Fashion Marketing and Management, 9, 420-433.

Yoh, E., \& Damhorst, M. L. (1999, November). Consumer adoption of the Internet for apparel shopping: Theoretical model development. Paper presented to the International Textile and Apparel Association, Santa Fe, NM.

Yoh, E., Damhorst, M., Sapp, S., \& Lazniak, R. (2003). Consumer adoption of the Internet: The case of apparel shopping. Psychology and Marketing, 20, 1095-1118.

Sharron J. Lennon is the Irma Ayers Professor in the Department of Fashion and Apparel Studies at the University of Delaware. She has published in a variety of journals, including Clothing and Textiles Research Journal, Psychology \& Marketing, Journal of Fashion Marketing and Management, Managing Service Quality, Journal of Consumer Marketing, Journal of the Textile Institute, Family and Consumer Sciences Research
Journal, and Journal of Business Research. Her current research interests focus on the online shopping environment and extreme consumption of fashion and apparel products.

Young $\mathrm{Ha}$ is an assistant professor in the Department of Textiles, Clothing, and Design at the University of Nebraska. She has published articles in journals such as Journal of Fashion Marketing and Management, Journal of Retail and Distribution Management, and Psychology $\mathcal{E}$ Marketing. Her research interest focuses on Internet marketing and retailing that covers consumer psychology, visual merchandising (Web site design), global marketing, and rural consumers and retailing.

Kim K. P. Johnson is a professor in the College of Design at the University of Minnesota. Her teaching and research interests are in the areas of consumer behavior and social psychological aspects of appearance.

Cynthia R. Jasper is a professor of consumer science at the University of Wisconsin-Madison. She has served as chair of the Consumer Science Department since 1996 and is currently chairing the Interdisciplinary Studies Department. In recognition of her research and other contributions, she received the Vaughn Bascom Professorship in Women and Philanthropy. She has published several refereed journal articles regarding apparel purchasing and consumer behavior and management within the retailing settings. Journals in which she has published include Clothing and Textiles Research Journal, Journal of Shopping Center Research, Journal of Small Business Management, Journal of Business Research, Journal of Small Business and Entrepreneurship, International Journal of Clothing Science and Technology, Journal of Business and Psychology, Journal of Advertising Research, International Review of Retail, Distribution and Consumer Research, and Journal of Consumer Affairs.

Mary Lynn Damhorst is a professor in the Department of Apparel, Educational Studies, and Hospitality Management at Iowa State University. Her research focuses on consumer behavior toward apparel and the body and dress as social discourse.

Nancy Lyons is associate professor of apparel merchandising at South Dakota State University. Her publications focus on rural consumers' online shopping attitudes and practices, fashion advertising (current and historic), students' gender type and comfort with the cross-dressing phenomenon, and organizational culture of a sewn-products manufacturer. 